\title{
PENGARUH KECERDASAN EMOSIONAL, MOTIVASI KERJA DAN KUALITAS KEHIDUPAN KERJA TERHADAP KINERJA PEGAWAI DI BADAN KEPEGAWAIAN DAERAH KABUPATEN LABUHANBATU SELATAN
}

\author{
${ }^{1}$ Rafidi M. Noor, ${ }^{2}$ Nurliana, ${ }^{3}$ Umar Nafi, ${ }^{4}$ Jonny Hutasoit, ${ }^{5}$ Juliawan Samsir Rajagukguk \\ $1,2,3,4,5$ Universitas Islam Sumatera Utara \\ rafidi.noor@gmail.com, ${ }^{2}$ nurliana,mm@gmail.com, ${ }^{3}$ umar.nafi@gmail.com, ${ }^{4}$ jonny.hutaosit@gmail.com, \\ 5juliawan,samsir@gmail.com
}

\begin{abstract}
Problem of this study how influence of emotional intellegence on performance. How influence of job motivation on performance. How influence of quality work of life on performance. How influence emotional intellegence, job motivation and quality work of life on performance. The purpose of this study to determine and analyze the effect of emotional intellegence on performance. Determine and analyze the effect of job motivation on performance. Determine and analyze the effect of quality work of life on performance. Determine and analyze the effect of emotional intellegence, job motivation and quality work of life on performance. Sample in the study is 34 employees. Data analysis techniques used in this study is descriptive analyze and multiple linear regression analysis. The results of the study indicate emotional intellegence variable has a positive and significant effect on performance. job motivation variable has a positive and significant effect on performance. quality work of life variable has a positive and significant effect on performance. Emotional intellegence, job motivation and quality work of life variable has a positive and significant effect on performance.
\end{abstract}

Keywords : Emotional intellegence, Job motivation, Quality work of life, Performance.

ABSTRAK : Rumusan masalah dalam penelitian ini adalah apakah ada pengaruh kecerdasan emosional terhadap kinerja. Apakah ada pengaruh motivasi kerja terhadap kinerja. Apakah ada pengaruh kualitas kehidupan kerja terhadap kinerja. Apakah ada pengaruh kecerdasan emosional, motivasi kerja dan kualitas kehidupan kerja terhadap kinerja. Tujuan penelitian ini adalah untuk mengetahui dan menganalisis pengaruh kecerdasan emosional terhadap kinerja. Untuk mengetahui dan menganalisis pengaruh motivasi kerja terhadap kinerja. Untuk mengetahui dan menganalisis pengaruh kualitas kehidupan kerja terhadap kinerja. Untuk mengetahui dan menganalisis pengaruh kecerdasan emosional, motivasi kerja dan kualitas kehidupan kerja terhadap kinerja. Sampel dalam penelitian ini berjumlah 34 orang pegawai. Teknik analisis data yang digunakan dalam penelitian ini adalah analisis deskriptif dan analisis regresi linier berganda. Hasil penelitian ini menjelaskan bahwa variabel kecerdasan emosional berpengaruh positif dan signifikan terhadap kinerja. Variabel motivasi kerja berpengaruh positif dan signifikan terhadap kinerja. Variabel kualitas kehidupan kerja berpengaruh positif dan signifikan terhadap kinerja. Variabel kecerdasan emosional, motivasi kerja, dan kualitas kehidupan kerja berpengaruh positif dan signifikan terhadap kinerja .

Kata kunci : Kecerdasan emosional, Motivasi kerja, Kualitas kehidupan kerja, Kinerja

\section{Pendahuluan}

Suatu organisasi baik itu bersifat profit maupun pelayanan publik dituntut untuk dapat menampilkan kinerja terbaiknya secara konsisten guna pencapaian tujuan organisasinya. Salah satu faktor yang menentukan pencapaian kinerja organisasi dan tujuan organisasi adalah kinerja sumber daya manusianya dalam hal ini pegawai. Posisi pegawai sebagai mesin birokrasi dituntut untuk bekerja secara efektif dan efisien dalam rangka memaksimalkan fungsi organisasi pemerintah. Selain tuntutan di atas tanggungjawab yang lain adalah menjaga serta memperbaiki citra para pegawai di mata masyarakat, karena sering di anggap sebagai pegawai yang tidak memiliki inovasi kerja yang tinggi sehingga kinerja organisasi dinilai kurang optimal. Kekuatan 
setiap organisasi terletak pada sumber daya manusia, sehingga prestasi organisasi tidak terlepas dari prestasi setiap individu yang terlibat didalamnya, dan prestasi akhir itulah yang dikenal dengan performance atau kinerja. Manajemen sumber daya manusia merupakan salah satu faktor kunci untuk mendapatkan kinerja terbaik, karena selain menangani masalah keterampilan dan keahlian, manajemen sumber daya manusia juga berkewajiban membangun perilaku kondusif individu untuk mendapatkan kinerja terbaik.

Untuk melancarkan tugasnya maka diperlukan pegawai yang mempunyai kemampuan yang baik, karena pegawai merupakan salah satu sumber daya organisasi yang mempunyai nilai prakarsa dan memiliki peran penting dalam pemberdayaan sumber daya lainnya dalam organisasi. Sistem pengelolaan Sumber Daya Manusia (SDM) yang tepat merupakan kunci keberhasilan organisasi untuk mencapai tujuannya. Oleh karena itu, agar tujuan dan sasaran organisasi dapat dicapai, perlu adanya perhatian yang lebih dari organisasi terhadap upaya-upaya dalam meningkatkan kinerja pegawai.

Pengertian kinerja menurut Mangkunegara (2015:67) adalah hasil kerja secara kualitas dan kuantitas yang dicapai oleh seorang pegawai dalam melaksanakan tugasnya sesuai dengan tanggung jawab yang diberikan kepadanya. Menurut Mangkuprawira (2014:13) kinerja merupakan singkatan dari kinetika energi kerja yang padanannya dalam bahasa inggris adalah perfomance, kinerja adalah keluaran yang dihasilkan oleh fungsi-fungsi atau indikatorindikator suatu pekerjaan atau suatu profesi dalam waktu tertentu. Nawawi dalam Widodo (2015:131) kinerja adalah hasil dari suatu pekerjaan yang telah dilakukan, baik berupa fisik atau material maupun non fisik atau non material. Untuk mengungkap fenomena tentang kinerja pegawai, peneliti melakukan pra survei dengan melakukan wawancara dan penyebaran angket terhadap 10 orang pegawai di Badan Kepegawaian Daerah Kabupaten Labuhanbatu Selatan. Dari hasil angket pra survei dapat ditarik kesimpulan bahwa inisitif pegawai untuk mencapai target kerja, 7 orang pegawai menyatakan belum dapat sepenuhnya dalam mencapai target kerja, sedangkan 3 orang pegawai mampu mencapai target keja yang menjadi beban dan tanggungjawabnya. Kemudian 6 orang pegawai belum mampu mempercepat menyelesaikan pekerjaan sebelum batas waktu yang ditentukan, dan 4 orang pegawai mampu menyelesaikan pekerjaan sebelum batas waktu yang ditentukan. Dari hasil angket pra survei dan wawancara tersebut jelas terlihat kinerja pegawai di Badan Kepegawaian Daerah Kabupaten Labuhanbatu Selatan masih perlu mendapat perhatian sengan memperhatikan faktor-faktor yang menjadi penyebabnya.

Untuk dapat meningkatkan kinerja pegawai di Badan Kepegawaian Daerah Kabupaten Labuhanbatu Selatan maka aspek kecerdasan emosional juga perlu ditingkatkan sehingga pegawai dapat bekerja sama dengan baik dalam tim. Kecerdasan emosional merupakan kecerdasan yang dimiliki seseorang untuk memotivasi diri dalam menghadapi kegagalan dan mengendalikan emosi, serta menunda kepuasan dalam mengatur keadaan jiwa. Beberapa penelitian terdahulu menarik kesimpulan bahwa kecerdasan emosional merupakan variabel yang dapat mempengaruhi kinerja pegawai secara langsung, walaupun masih terdapat riset gap tentang pengaruh kecerdasan emosional terhadap kinerja. Hasil penelitian terdahulu yang dilakukan oleh Ari Soeti Yani dan Ayu Istiqomah (2016); dan Thea et.al (2019) menarik kesimpulan kecerdasan emosional berpengaruh negatif dan tidak signifikan terhadap kinerja. Hasil penelitian lain dilakukan oleh Danquah, M. E. (2014); Gani et.al (2018); Supriadi dan Sefnedi (2017), kesemuanya menarik kesimpulan adanya pengaruh positif dan signifikan antara kecerdasan emosional terhadap kinerja. Dari beberapa penelitian terdahulu tersebut menunjukkan adanya riset gap, sehingga hal ini menarik peneliti untuk melakukan penelitian lanjutan di Badan Kepegawaian Daerah Kabupaten Labuhanbatu Selatan.

Permasalahan lainnya tentang kinerja pegawai di Badan Kepegawaian Daerah Kabupaten Labuhanbatu Selatan dipengaruhi oleh faktor kualitas kehidupan kerja. Setiap orang yang bekerja pada sebuah instansi, mengharapkan lingkungan kerja yang nyaman, rekan-rekan kerja yang bisa di ajak untuk bersinergi, adanya dukungan dari atasan dalam pengembangan diri. Semua hal tersebut dapat terpenuhi dengan pelaksanaan aspek yang terkandung dalam kualitas kehidupan kerja atau QWL. Menurut Wibowo (2017: 107), dengan usaha memaksimalkan kualitas kehidupan kerja di instansi dapat memunculkan peranan para pegawai, untuk perbaikan kinerja dan 
produktivitas. Selain itu, pemberian kualitas kehidupan kerja yang memadai juga merupakan bentuk penghargaan terhadap kemampuan para pegawai yang memiliki sebuah komitmen pada instansi. Mereka akan ditujukan terhadap sumber daya yang dimiliki beserta manajemen instansi agar nantinya mengembangkan lingkungan kerja dan dapat memberikan kontribusi terhadap perbaikan kinerja mereka. Para pegawai yang bekerja menginginkan pekerjaan yang mampu memenuhi kebutuhan materil dan non materil. Bukan hanya pekerjaan yang memberikan penghasilan tetapi juga pekerjaan yang mampu memberikan tambahan ilmu, dan membuat mereka merasa bermakna berada. Penelitian terdahulu yang menjelaskan bahwa kualitas kehidupan kerja berpengaruh terhadap kinerja pegawai yaitu Majundar (2012) melakukan penelitian terhadap 108 orang pegawai industri Telkom di Indian, hasil penelitian menunjukkan ada hubungan yang signifikan antara quality of work life dengan kinerja pegawai. Selanjutnya penelitian dari Taghavi (2014) terhadap 180 orang guru SMA di Shirvan, hasil penelitian juga menunjukkan quality of work life memiliki hubungan yang signifikan terhadap efektivitas kinerja guru SMA di Shirvan. Fenomena yang terjadi pada pegawai di Badan Kepegawaian Daerah Kabupaten Labuhanbatu Selatan diantarnya masih kurangnya pengayaan akan kemampuan kerja staf, masih rendahnya kesempatan staf untuk mengembangkan kemampuan diri, dan masih rendahnya penghargaan yang diberikan kepada staf, rendahnya kemampuan untuk memanfaatkan teknologi informasi yang ada.

Faktor berikutnya yang diduga dapat mempengaruhi kinerja pegawai di Badan Kepegawaian Daerah Kabupaten Labuhanbatu Selatan adalah motivasi kerja. Menurut Rivai (2009:223) menyatakan bahwa 35\% dari waktu para pimpinan digunakan untuk mengawasi masalah lingkungan manusia (pegawai). Pendekatan yang digunakan dalam memberikan motivasi pada pegawai perlu memperhatikan karesteristik pegawai yang bersangkutan. Dessler (2011:88) membandingkan antara pegawai dan supervisor sektor publik dan swasta memberikan hasil yang berbeda. Pada pegawai sektor publik lebih cendrung motivasi kerja mereka disebabkan oleh adanya kestabilan dan keamanan dalam bekerja dimasa mendatang sebagai faktor utama yang berpengaruh. Sedangkan untuk pegawai sektor swasta motivasi mereka bekerja sangat dipengaruhi oleh tingginya gaji yang mereka peroleh dan kesempatan untuk meraih jenjang yang lebih tinggi. Pada tingkat supervisor, motivasi pegawai dalam bekerja pada instansi publik dipengaruhi oleh keterlibatan mereka dalam memberikan kontribusi dalam membuat keputusan-keputusan yang penting. Selain itu kestabilan dan keamanan kerja masih dominan untuk instansi publik. Untuk melihat fenomena tentang motivasi kerja di Badan Kepegawaian Daerah Kabupaten Labuhanbatu Selatan dilihat dari absensi pegawai 2 bulan terakhir (Januari 2021 s/d Februari 2021). Berdasarkan data absensi dapat dilihat bahwa rata-rata keterlambatan pegawai masuk kerja selama 2 bulan terakhir adalah $9 \%$ dan rata-rata pegawai yang pulang sebelum jam kerja adalah $11 \%$. Kondisi ini merefleksikan bahwa motivasi kerja pegawai di Kantor Kesyahbandaran Utama Belawan masih perlu mendapat perhatian. Hasil penelitian terdahulu dari Agus Marimin (2011); Ali, A.Y.S., Dahie, A.M., dan Ali, A.A. (2016); Murgianto, Sulasmi, S., dan Suhermin. (2016); Nisyak, Ila Rohmatun., dan Trijonowati. (2016); Noviansyah dan Zunaidah (2011); Saeed, S., dan Syah, F.M (2016); Yazid, Musnadi dan Chan, (2013), kesemuanya menyatakan motivasi berpengaruh signifikan terhadap kinerja.

\subsection{Rumusan Masalah}

Berdasarkan batasan masalah yang telah diidentifikasi maka peneliti merumuskan masalah yang berkaitan dengan penelitian ini adalah :

1) Apakah ada pengaruh kecerdasan emosional terhadap kinerja pegawai di Badan Kepegawaian Daerah Kabupaten Labuhanbatu Selatan.

2) Apakah ada pengaruh motivasi kerja terhadap kinerja pegawai di Badan Kepegawaian Daerah Kabupaten Labuhanbatu Selatan

3) Apakah ada pengaruh kualitas kehidupan kerja terhadap kinerja pegawai di Badan Kepegawaian Daerah Kabupaten Labuhanbatu Selatan.

4) Apakah ada pengaruh kecerdasan emosional, motivasi kerja dan kualitas kehidupan kerja terhadap kinerja pegawai di Badan Kepegawaian Daerah Kabupaten Labuhanbatu Selatan. 


\subsection{Batasan Masalah}

Berdasarkan pada uraian di atas, banyak faktor yang teridentifikasi terkait pada variabel penelitian. Oleh karena itu peneliti membatasi permasalahan dalam penelitian ini hanya pada masalah kecerdasan emosional, motivasi kerja, kualitas kehidupan kerja dan kinerja.

\subsection{Hipotesis}

Berdasarkan pada kerangka konseptual di atas, maka hipotesis dalam penelitian ini adalah

1) Ada pengaruh kecerdasan emosional terhadap kinerja pegawai di Badan Kepegawaian Daerah Kabupaten Labuhanbatu Selatan.

2) Ada pengaruh motivasi kerja terhadap kinerja pegawai di Badan Kepegawaian Daerah Kabupaten Labuhanbatu Selatan.

3) Ada pengaruh kualitas kehidupan kerja kerja terhadap kinerja pegawai di Badan Kepegawaian Daerah Kabupaten Labuhanbatu Selatan.

4) Ada pengaruh kecerdasan emosional, motivasi kerja dan kualitas kehidupan kerja terhadap kinerja pegawai di Badan Kepegawaian Daerah Kabupaten Labuhanbatu Selatan.

\subsection{Tujuan Penelitian}

Tujuan dari penelitian ini adalah :

1) Untuk menganalisis pengaruh kecerdasan emosional terhadap kinerja pegawai di Badan Kepegawaian Daerah Kabupaten Labuhanbatu Selatan.

2) Untuk menganalisis pengaruh motivasi kerja terhadap kinerja pegawai di Badan
Kepegawaian Daerah Kabupaten

Labuhanbatu Selatan

3) Untuk menganalisis pengaruh kualitas kehidupan kerja terhadap kinerja pegawai di Badan Kepegawaian Daerah Kabupaten Labuhanbatu Selatan.

4) Untuk menganalisis pengaruh kecerdasan emosional, motivasi kerja dan kualitas kehidupan kerja terhadap kinerja pegawai di Badan Kepegawaian Daerah Kabupaten Labuhanbatu Selatan.

\section{Metode Penelitian \\ 2.1. Populasi}

Menurut Sugiyono (2014:55), populasi adalah wilayah generalisasi yang terdiri atas obyek/subjek yang mempunyai kuantitas dan karakteristik tertentu yang ditetapkan oleh peneliti untuk dipelajari dan kemudian ditarik kesimpulannya. Jadi populasi bukan hanya orang tetapi juga benda-benda alam yang lain. Populasi juga bukan sekedar jumlah yang ada pada objek/subjek yang dipelajari, tetapi meliputi seluruh karakteristik, sifat yang dimiliki objek/subjek itu. Dari pengertian tersebut, maka dapat disimpulkan bahwa populasi merupakan subjek penelitian dimana individu yang akan dikenai perilaku atau dapat dikatakan sebagai keseluruhan objek penelitian yang akan diteliti. Maka populasi dalam penelitian ini adalah para pegawai Badan Kepegawaian Daerah Kabupaten Labuhanbatu Selatan yang berjumlah 34 orang. dimana Kepala Badan dan peneliti tidak dihitung sebagai populasi.

Tabel 1. Kerangka populasi pegawai

\begin{tabular}{|c|l|c|}
\hline No & \multicolumn{1}{|c|}{ Keterangan } & Jumlah (Orang) \\
\hline 1 & Sekretariat & 10 \\
\hline 2 & Bidang Program Pendataan Kepegawaian & 8 \\
\hline 3 & Bidang Mutasi & 9 \\
\hline 4 & Bidang Pengembangan dan Pemberdayaan Pegawai & 7 \\
\hline \multicolumn{2}{|c|}{ Jumlah } & 34 \\
\hline \multicolumn{2}{|c|}{ Sumber : BKD Kabupaten Labusel, 2021 }
\end{tabular}

\subsection{Sampel}

Menurut Sugiyono (2011:93), sampel adalah elemen-elemen populasi yang dipilih atas dasar kemampuan mewakilinya. Untuk menjadi pedoman jika subjeknya atau populasinya kurang dari 100, maka lebih baik diambil semua sebagai sampel, sehingga penelitiannya merupakan penelitian populasi.
Selanjutnya jika jumlah subjeknya atau populasinya besar atau lebih dari 100, maka dapat diambil persentasenya. Dengan menggunakan teknik penarikan sampel yaitu total sampling atau metode sensus, maka sampel dalam penelitian ini berjumlah 34 orang pegawai di Badan Kepegawaian Daerah Kabupaten Labuhanbatu Selatan. 
Tabel 2. Kerangka sampel pegawai

\begin{tabular}{|c|l|c|}
\hline No & \multicolumn{1}{|c|}{ Keterangan } & Jumlah (Orang) \\
\hline 1 & Sekretariat & 10 \\
\hline 2 & Bidang Program Pendataan Kepegawaian & 8 \\
\hline 3 & Bidang Mutasi & 9 \\
\hline 4 & Bidang Pengembangan dan Pemberdayaan Pegawai & 7 \\
\hline \multicolumn{2}{|c|}{ Jumlah } & 34 \\
\hline
\end{tabular}

Sumber : BKD Kabupaten Labusel, 2021

\subsection{Uji Normalitas}

Model regresi yang baik adalah yang memiliki nilai residual yang terdistribusi normal. Untuk mengetahui bentuk distribusi data, bisa dilakukan dengan grafik distribusi dan analisis statistik. Pengujian dengan distribusi dilakukan dengan melihat grafik histogram yang membandingkan antara dua observasi dengan distribusi yang mendekati distribusi normal. Distribusi normal akan membentuk satu garis lurus diagonal dan ploating data residual akan dibandingkan dengan garis diagonal. Jika distribusi atau residual normal, maka garis yang menggambarkan data yang sesungguhnya akan mengikuti garis diagonalnya. Uji normalitas dengan grafik dapat dilakukan dengan program SPSS dengan analisis grafik Normal Probability Plot

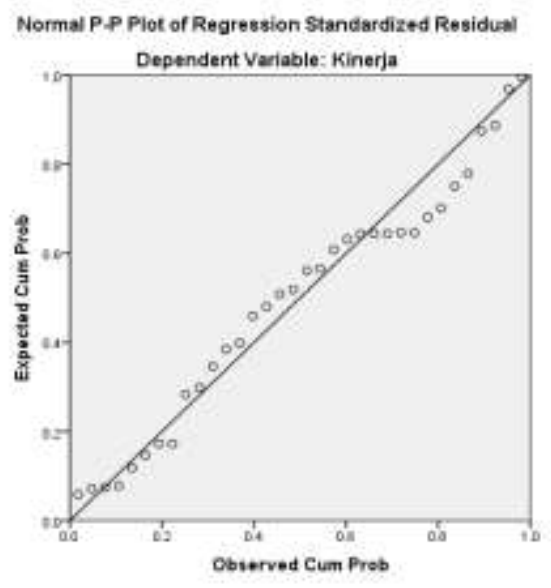

Gambar 1. Uji normalitas data

Berdasarkan gambar 1, diatas terlihat titiktitik dari ploating data residual berada di garis diagonal, hal ini dapat disimpulkan data yang diuji berdistribusi normal.

\subsection{Uji Multikolinieritas}

Salah satu asumsi dari model regresi linier bahwa tidak terjadi korelasi yang signifikan antara variabel bebasnya. Untuk menguji hal tersebut maka diperlukan suatu uji yang disebut uji multikolinieritas. Menurut Duwi Priyatno (2012:151) pengertian multikolinieritas adalah keadaan di mana pada model regresi ditemukan adanya korelasi yang sempurna atau mendekati sempurna antar variabel independen. Pada regresi yang baik seharusnya tidak terjadi korelasi yang sempurna atau mendekati sempurna diantara variabel bebas. Uji multikolinieritas adalah untuk melihat ada atau tidaknya korelasi yang tinggi antara variabelvariabel bebasnya, maka hubungan antara variabel bebas terhadap variabel terikatnya menjadi terganggu. Jika terdapat korelasi yang kuat dimana sesama variabel independen maka konsekuensinya adalah :

a. Koefisien-koefisien regresi menjadi tidak dapat ditaksir

b. Nilai standar error setiap koefisien regresi menjadi tidak terhingga.

Dengan demikian, semakin besar korelasi diantara sesama variabel independen maka tingkat kesalahan dari koefisien regresi semakin besar yang dapat mengakibatkan standar error semakin besar pula. Cara yang digunakan untuk mendeteksi ada tidaknya multikolinieritas adalah dengan melihat besarnya nilai Variance Inflation Factor (VIF). Jika VIF dibawah 10 dan Tolerance Value diatas 0,1 maka tidak terjadi multikolinieritas.

Tabel 3. Uji multikolinieritas

\begin{tabular}{|l|c|c|}
\hline \multirow{2}{*}{ Variabel } & \multicolumn{2}{|c|}{ Collinearity Statistics } \\
\cline { 2 - 3 } & Tolerance & VIF \\
\hline $\begin{array}{l}\text { Kecerdasan } \\
\text { emosional }\end{array}$ & 0.665 & 1.503 \\
\hline Motivasi kerja & 0.989 & 1.011 \\
\hline $\begin{array}{l}\text { Kualitas kehidupan } \\
\text { kerja }\end{array}$ & 0.669 & 1.495 \\
\hline
\end{tabular}

a. Dependent Variable : Kinerja

Hasil pengolahan data, 2021

Berdasarkan Tabel 3 diatas diperoleh nilai Tolerance Value diatas 0.1 yaitu 0.665 , 0.989, dan 0.669 , hal ini menunjukan adanya korelasi yang cukup tinggi/kuat antara sesama variabel bebas dan nilai Variance Inflantion Factorrs 
(VIF) sebesar 1.503, 1.011, dan 1.495, dimana nilai VIF dari ketiga varibel bebas lebih kecil dari 10 dan dapat disimpulkan tidak terdapat multikolinieritas diantara ketiga variabel bebas yang diuji dalam penelitian ini.

\subsection{Uji Autokorelasi}

Uji autokorelasi merupakan pengujian dimana variabel dependen tidak berkorelasi dengan nilai variabel itu sendiri, baik nilai periode sebelumnya maupun nilai periode sesudahnya. Menurut Duwi Priyatno (2012:172) pengertian dari autokorelasi adalah keadaan di mana pada model regresi ada korelasi antara residual pada periode tertentu $t$ dengan residual pada periode sebelumnya (t-1), model regresi yang baik adalah yang tidak terdapat masalah autokorelasi. Metode pengujian menggunakan uji Durbin-Watson (DW-test). Salah satu ukuran dalam menentukan ada tidaknya masalah autokorelasi dengan uji Durbin-Watson (DW) dengan ketentuan sebagai berikut :

- Terjadi autokorelasi positif jika nilai DW dibawah -2 atau DW $<-2$

- Tidak terjadi autokorelasi jika nilai DW diantara -2 dan +2 atau $-2<$ DW $<+2$

- Terjadi autokorelasi negatif jika nilai DW di atas 2 atau DW $>2$.

Tabel 4. Uji Autokorelasi

\begin{tabular}{|c|c|c|c|c|c|c|}
\hline \multirow[b]{2}{*}{ Model } & \multicolumn{5}{|c|}{ Change Statistics } & \multirow{2}{*}{$\begin{array}{l}\text { Durbin- } \\
\text { Watson }\end{array}$} \\
\hline & $\begin{array}{c}\text { R Square } \\
\text { Change }\end{array}$ & F Change & df1 & df2 & $\begin{array}{c}\text { Sig. } F \\
\text { Change }\end{array}$ & \\
\hline 1 & .718 & 25.521 & 3 & 30 & .000 & 2.002 \\
\hline
\end{tabular}

Berdasarkan Tabel 4 di atas diperoleh nilai Durbin-Watson (DW) sebesar 2.002, nilai ini berada pada kisaran $-2<\mathrm{DW}<+2$, maka dapat disimpulkan bahwa tidak terjadi autokorelasi pada model regresi dalam penelitian ini.

\subsection{Uji Heteroskedastisitas}

Uji heteroskedastisitas bertujuan untuk menguji apakah dalam model regresi terjadi ketidaksamaan variance dari residual satu pengamatan ke pengamatan yang lainnya. Gejala variance yang tidak sama ini disebut dengan heteroskedastisitas, sedangkan adanya gejala residual yang sama dari satu pengamatan ke pengamatan lain disebut dengan homokedastisitas. Menurut Duwi Priyatno (2012:158) pengertian dari heteroskedastisitas adalah dimana dalam model regresi tejadi ketidaksamaan varian dari residual pada suatu pengamatan ke pengamatan yang lain. Model regresi yang baik adalah tidak terjadi heteroskedastisitas. Berbagai macam uji heteroskedastisitas yaitu dengan uji glejser, melihat pola titik-titik pada scatterplots regresi, atau uji koefisien korelasi spearman's.

Uji heteroskedastisitas dapat dilakukan dengan menggunakan grafik scatterplot antara nilai variabel terikat (ZSPRED) dengan residualnya (SRESID), dimana sumbu $X$ adalah yang diprediksi dan sumbu $\mathrm{Y}$ adalah residual. Dasar pengambilan keputusan yang dapat diambil adalah sebagai berikut : a. Jika pola tertentu seperti titik-titik yang ada membentuk suatu pola yang teratur (bergelombang, melebar kemudian menyempit) maka telah terjadi heteroskedastisitas.

b. Jika tidak ada yang jelas serta titik-titik menyebar diatas dan dibawah angka nol pada sumbu $\mathrm{Y}$ maka tidak terjadi heteroskedastisitas

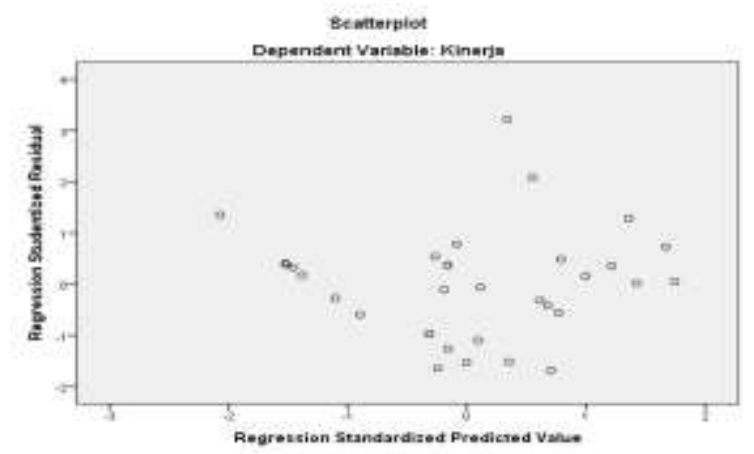

Gambar 2. Uji heteroskedastisitas

Berdasarkan gambar 2, diatas, menunjukkan titik-titik yang menyebar, sehingga dapat disimpulkan tidak terjadi heteroskedastisitas di data penelitian ini.

\section{Evaluasi Data}

Dalam evaluasi data ini peneliti akan melihat model persamaan regresi berganda dan akan menguji kebenaran hipotesis baik itu secara partial atau sendiri-sendiri, maupun secara simultan atau bersama-sama, dan untuk 
memudahkan peneliti dalam pengolahan data, maka digunakan Program Statistical Product and Service Solutions versi 22.00.

\subsection{Analisis Regresi Linier Berganda.}

Analisis regresi linier berganda dalam penelitian ini dapat dilihat dari persamaan regresinya, dan dari hasil pengolahan data diperoleh hasil berikut ini :

Tabel 5. Analisis regresi linier berganda

\begin{tabular}{|c|c|c|c|c|c|}
\hline \multirow[t]{2}{*}{ Model } & \multicolumn{2}{|c|}{$\begin{array}{c}\text { Unstandardized } \\
\text { Coefficients }\end{array}$} & \multirow{2}{*}{$\begin{array}{c}\text { Standardized } \\
\text { Coefficients } \\
\text { Beta }\end{array}$} & \multirow[t]{2}{*}{$\mathrm{t}$} & \multirow[t]{2}{*}{ Sig. } \\
\hline & B & Std. Error & & & \\
\hline (Constant) & 1.087 & 5.295 & & .016 & .987 \\
\hline Kecerdasan emosional & .410 & .103 & .471 & 3.969 & .000 \\
\hline Motivasi kerja & .153 & .077 & .294 & 2.990 & .006 \\
\hline $\begin{array}{l}\text { Kualitas kehidupan } \\
\text { kerja }\end{array}$ & .440 & .120 & .437 & 3.686 & .001 \\
\hline
\end{tabular}

Hasil pengolahan data, 2021

Berdasarkan Tabel 5.18, diatas dapat dibuat persamaan regresi dalam penelitian ini sebagai berikut :

$\mathrm{Y}=1.087+0.410 \mathrm{X}_{1}+0.153 \mathrm{X}_{2}+0.440 \mathrm{X}_{3}+\mathrm{e}$

Dari persamaan regresi linier berganda di atas dapat dijelaskan :

1) Nilai kinerja pegawai di Badan Kepegawaian Daerah Kabupaten Labuhanbatu Selatan sebesar 1.087, yang mana nilai dari variabel dari variabel kecerdasan emosional, motivasi kerja dan kualitas kehidupan kerja diabaikan.

2) Nilai koefisien regresi $X_{1}$ (kecerdasan emosional) mempunyai nilai positif yaitu 0.410 , hal ini menunjukkan bahwa variabel kecerdasan emosional mempunyai pengaruh yang searah dan positif terhadap kinerja pegawai di Badan Kepegawaian Daerah Kabupaten Labuhanbatu Selatan.

3) Nilai koefisien regresi $X_{2}$ (motivasi kerja) mempunyai nilai positif yaitu 0.153 , hal ini menunjukkan bahwa variabel motivasi kerja mempunyai pengaruh yang searah dan positif terhadap kinerja pegawai di Badan Kepegawaian Daerah Kabupaten Labuhanbatu Selatan.

4) Nilai koefisien regresi $X_{3}$ (kualitas kehidupan kerja) mempunyai nilai positif yaitu 0.440 , hal ini menunjukkan bahwa variabel kualitas kehidupan kerja mempunyai pengaruh yang searah dan positif terhadap kinerja pegawai di Badan Kepegawaian Daerah Kabupaten Labuhanbatu Selatan.

\subsection{Uji Hipotesis}

\subsubsection{Pengaruh Kecerdasan Emosional Terhadap Kinerja Pegawai di Badan Kepegawaian Daerah Kabupaten Labuhanbatu Selatan.}

Untuk mengetahui pengaruh kecerdasan emosional terhadap kinerja pegawai di Badan Kepegawaian Daerah Kabupaten Labuhanbatu Selatan digunakan uji-t, sedangkan untuk melihat besarnya pengaruh digunakan nilai Beta atau Standardized Coefficient Beta.

Tabel. 6. Pengaruh kecerdasan emosional terhadap kinerja

\begin{tabular}{|l|c|r|r|r|r|}
\hline \multirow{2}{*}{ Model } & \multicolumn{2}{|c|}{$\begin{array}{c}\text { Unstandardized } \\
\text { Coefficients }\end{array}$} & $\begin{array}{c}\text { Standardized } \\
\text { Coefficients } \\
\text { Beta }\end{array}$ & \multirow{2}{*}{$\mathrm{t}$} & \multirow{2}{*}{ Sig. } \\
\cline { 2 - 3 } & \multicolumn{1}{c|}{$\mathrm{B}$} & \multicolumn{1}{|c|}{ Std. Error } & & \\
\hline (Constant) & 1.087 & 5.295 & & .016 & .987 \\
\hline Kecerdasan emosional & .410 & .103 & .471 & 3.969 & .000 \\
\hline
\end{tabular}

a. Dependent Variable : Kinerja

Hasil pengolahan data, 2021

Dari Tabel 6 diatas diperoleh nilai $\mathrm{t}_{\text {hitung }}$ sebesar 3.969. Penelitian ini menggunakan taraf signifikansi $(\alpha: 0.05)$ dan Derajat Kebebasan (DK) dengan ketentuan DK $=\mathrm{n}-2$, atau $34-2$ $=32$. Dengan ketentuan tersebut, diperoleh nilai $\mathrm{t}_{\text {tabel }}$ sebesar 2.036. Dengan kriteria hipotesis sebagai berikut :
Jika $t_{\text {hitung }}>t_{\text {tabel }}$, maka $\mathrm{H}_{0}$ ditolak dan $\mathrm{H}_{1}$ diterima.

Jika $\mathrm{t}_{\text {hitung }}<\mathrm{t}_{\text {tabel }}$, maka $\mathrm{H}_{0}$ diterima dan $\mathrm{H}_{1}$ ditolak.

Dari hasil pengolahan data diperoleh nilai $t_{\text {hitung }}>t_{\text {tabel }}(3.969>2.036)$ dan nilai signifikasi lebih kecil dari nilai $\alpha: 0.05$ yaitu $0.000<0.05$, 
sehingga $\mathrm{H}_{0}$ ditolak dan $\mathrm{H}_{1}$ diterima. Artinya variabel kecerdasan emosional secara partial berpengaruh positif dan signifikan terhadap kinerja pegawai di Badan Kepegawaian Daerah Kabupaten Labuhanbatu Selatan. Besarnya pengaruh variabel kecerdasan emosional terhadap kinerja pegawai di Badan Kepegawaian Daerah Kabupaten Labuhanbatu Selatan sebesar 0.471 atau $47.10 \%$.

\subsubsection{Pengaruh Motivasi Kerja Terhadap Kinerja Pegawai di Badan Kepegawaian Daerah Kabupaten Labuhanbatu Selatan.}

Untuk mengetahui pengaruh motivasi kerja terhadap kinerja pegawai di Badan Kepegawaian Daerah Kabupaten Labuhanbatu Selatan digunakan uji-t, sedangkan untuk melihat besarnya pengaruh digunakan nilai Beta atau Standardized Coefficient Beta.

Tabel. 7. Pengaruh motivasi kerja terhadap kinerja

\begin{tabular}{|l|r|r|r|r|r|}
\hline \multirow{2}{*}{ Model } & \multicolumn{2}{|c|}{$\begin{array}{c}\text { Unstandardized } \\
\text { Coefficients }\end{array}$} & \multirow{2}{*}{$\begin{array}{c}\text { Standardized } \\
\text { Coefficients } \\
\text { Beta }\end{array}$} & \multirow{2}{*}{$\mathrm{t}$} & \multirow{2}{*}{ Sig. } \\
\cline { 2 - 3 } & \multicolumn{1}{|c|}{$\mathrm{B}$} & \multicolumn{1}{|c|}{ Std. Error } & & \\
\hline (Constant) & 1.087 & 5.295 & & .016 & .987 \\
\hline Motivasi kerja & .153 & .077 & .294 & 2.990 & .006 \\
\hline
\end{tabular}

a. Dependent Variable : Kinerja

Hasil pengolahan data, 2021

Dari Tabel 7 diatas diperoleh nilai $t_{\text {hitung }}$ sebesar 2.990. Penelitian ini menggunakan taraf signifikansi $(\alpha: 0.05)$ dan Derajat Kebebasan (DK) dengan ketentuan DK $=\mathrm{n}-2$, atau $34-2$ $=32$. Dengan ketentuan tersebut, diperoleh nilai $\mathrm{t}_{\text {tabel }}$ sebesar 2.036. Dengan kriteria hipotesis sebagai berikut :

Jika $t_{\text {hitung }}>t_{\text {tabel }}$, maka $\mathrm{H}_{0}$ ditolak dan $\mathrm{H}_{1}$ diterima.

Jika $\mathrm{t}_{\text {hitung }}<\mathrm{t}_{\text {tabel }}$, maka $\mathrm{H}_{0}$ diterima dan $\mathrm{H}_{1}$ ditolak.

Dari hasil pengolahan data diperoleh nilai $t_{\text {hitung }}>t_{\text {tabel }}(2.990>2.036)$ dan nilai signifikasi lebih kecil dari nilai $\alpha: 0.05$ yaitu $0.006<0.05$, sehingga $\mathrm{H}_{0}$ ditolak dan $\mathrm{H}_{1}$ diterima. Artinya variabel motivasi kerja secara partial berpengaruh positif dan signifikan terhadap kinerja pegawai di Badan Kepegawaian Daerah
Kabupaten Labuhanbatu Selatan. Besarnya pengaruh variabel motivasi kerja terhadap kinerja pegawai di Badan Kepegawaian Daerah Kabupaten Labuhanbatu Selatan sebesar 0.294 atau $29.40 \%$.

\subsubsection{Pengaruh Kualitas Kehidupan Kerja Terhadap Kinerja Pegawai di Badan Kepegawaian Daerah Kabupaten Labuhanbatu Selatan.}

Untuk mengetahui pengaruh kualitas kehidupan kerja terhadap kinerja pegawai di Badan Kepegawaian Daerah Kabupaten Labuhanbatu Selatan digunakan uji-t, sedangkan untuk melihat besarnya pengaruh digunakan nilai Beta atau Standardized Coefficient Beta.

Tabel. 8. Pengaruh kualitas kehidupan kerja terhadap kinerja

\begin{tabular}{|c|c|c|c|c|c|}
\hline \multirow[t]{2}{*}{ Model } & \multicolumn{2}{|c|}{$\begin{array}{c}\text { Unstandardized } \\
\text { Coefficients }\end{array}$} & \multirow{2}{*}{$\begin{array}{c}\text { Standardized } \\
\text { Coefficients } \\
\text { Beta }\end{array}$} & \multirow[t]{2}{*}{$\mathrm{t}$} & \multirow[t]{2}{*}{ Sig. } \\
\hline & $\mathrm{B}$ & Std. Error & & & \\
\hline (Constant) & 1.087 & 5.295 & & .016 & .987 \\
\hline $\begin{array}{l}\text { Kualitas kehidupan } \\
\text { kerja }\end{array}$ & .440 & .120 & .437 & 3.686 & .001 \\
\hline
\end{tabular}

a. Dependent Variable : Kinerja

Hasil pengolahan data, 2021

Dari Tabel 8 diatas diperoleh nilai $\mathrm{t}_{\text {hitung }}$ sebesar 3.686. Penelitian ini menggunakan taraf signifikansi $(\alpha: 0.05)$ dan Derajat Kebebasan (DK) dengan ketentuan DK $=\mathrm{n}-2$, atau $34-2$
$=32$. Dengan ketentuan tersebut, diperoleh nilai $\mathrm{t}_{\text {tabel }}$ sebesar 2.036. Dengan kriteria hipotesis sebagai berikut : 
Jika $t_{\text {hitung }}>t_{\text {tabel }}$, maka $\mathrm{H}_{0}$ ditolak dan $\mathrm{H}_{1}$ diterima.

Jika $\mathrm{t}_{\text {hitung }}<\mathrm{t}_{\text {tabel }}$, maka $\mathrm{H}_{0}$ diterima dan $\mathrm{H}_{1}$ ditolak.

Dari hasil pengolahan data diperoleh nilai $t_{\text {hitung }}>t_{\text {tabel }}(3.686>2.036)$ dan nilai signifikasi lebih kecil dari nilai $\alpha: 0.05$ yaitu $0.001<0.05$, sehingga $\mathrm{H}_{0}$ ditolak dan $\mathrm{H}_{1}$ diterima. Artinya variabel kualitas kehidupan kerja secara partial berpengaruh positif dan signifikan terhadap kinerja pegawai di Badan Kepegawaian Daerah Kabupaten Labuhanbatu Selatan. Besarnya pengaruh variabel kualitas kehidupan kerja terhadap kinerja pegawai Badan Kepegawaian

Tabel 9. Pengaruh kecerdasan emosional, mo
Daerah Kabupaten Labuhanbatu Selatan sebesar 0.437 atau $43.70 \%$.

\subsubsection{Pengaruh Kecerdasan Emosional, Motivasi Kerja dan Kualitas Kehidupan Kerja Terhadap Kinerja Pegawai di Badan Kepegawaian Daerah Kabupaten Labuhanbatu Selatan}

Untuk mengetahui pengaruh kecerdasan emosional, motivasi kerja dan kualitas kehidupan kerja terhadap kinerja pegawai Badan Kepegawaian Daerah Kabupaten Labuhanbatu Selatan digunakan uji-F.

tivasi kerja dan kualitas kehidupan kerja terhadap kinerja

\begin{tabular}{|l|l|r|r|r|r|c|}
\hline Model & & $\begin{array}{c}\text { Sum of } \\
\text { Squares }\end{array}$ & \multicolumn{1}{c|}{ df } & $\begin{array}{c}\text { Mean } \\
\text { Square }\end{array}$ & \multicolumn{1}{c|}{ F } & Sig. \\
\hline \multirow{3}{*}{1} & Regression & 287.476 & 3 & 95.825 & 25.521 & $.000^{\mathrm{b}}$ \\
\cline { 2 - 7 } & Residual & 112.642 & 30 & 3.755 & & \\
\cline { 2 - 7 } & Total & 400.118 & 33 & & & \\
\hline
\end{tabular}

Dependent Variable : Kinerja

Hasil pengolahan data, 2021

Dari Tabel 9 di atas diperoleh nilai $F_{\text {hitung }}$ sebesar 25.521. Penelitian ini menggunakan taraf signifikansi $(\alpha: 0.05)$ dan Derajat Kebebasan (DK) dengan ketentuan numerator : jumlah variabel -1 atau $4-1=3$, dan jumlah sampel dikurang 4 atau $34-4=30$. Dengan ketentuan tersebut, diperoleh nilai $\mathrm{F}_{\text {tabel }}$ sebesar 3.330. Dengan kriteria pengujian hipotesis sebagai berikut :

Jika $\mathrm{F}_{\text {hitung }}>\mathrm{F}_{\text {tabel }}$, maka $\mathrm{H}_{0}$ ditolak dan $\mathrm{H}_{1}$ diterima.

Jika $\mathrm{F}_{\text {hitung }}<\mathrm{F}_{\text {tabel }}$, maka $\mathrm{H}_{0}$ diterima dan $\mathrm{H}_{1}$ ditolak.

Dari hasil perhitungan diperoleh nilai $\mathrm{F}_{\text {hitung }}$ $>\mathrm{F}_{\text {tabel }}(25.521>3.330)$ dan nilai signifikasi $0.000<0.05$, sehingga $\mathrm{H}_{0}$ ditolak dan $\mathrm{H}_{1}$ diterima. Artinya variabel kecerdasan emosional, motivasi kerja dan kualitas kehidupan kerja secara simultan berpengaruh

positif dan signifikan terhadap kinerja pegawai di Badan Kepegawaian Daerah Kabupaten Labuhanbatu Selatan. Dengan demikian model regresi ini sudah layak dan benar dan dapat disimpulkan bahwa variabel kecerdasan emosional, motivasi kerja dan kualitas kehidupan kerja berpengaruh terhadap kinerja pegawai di Badan Kepegawaian Daerah Kabupaten Labuhanbatu Selatan.

\subsection{Uji Determinan}

Uji determinan adalah untuk mengetahui seberapa besar pengaruh variabel kecerdasan emosional, motivasi kerja dan kualitas kehidupan kerja terhadap kinerja pegawai Badan Kepegawaian Daerah Kabupaten Labuhanbatu Selatan, dan dapat dilihat dari model summary, khususnya nilai Rsquare.

Tabel 10. . Model summary ${ }^{\mathrm{b}}$ pengaruh kecerdasan emosional, motivasi kerja dan kualitas kehidupan kerja terhadap kinerja

\begin{tabular}{|c|c|c|c|c|}
\hline Model & $\mathrm{R}$ & $R$ Square & $\begin{array}{l}\text { Adjusted } R \\
\text { Square }\end{array}$ & Std. Error of the Estimate \\
\hline 1 & $.848^{\mathrm{a}}$ & .718 & .690 & 1.93771 \\
\hline
\end{tabular}

Dependent Variable : Kinerja

Hasil pengolahan data, 2021

Besarnya Tabel 10. diatas diperoleh nilai Rsquare $\left(\mathrm{r}^{2}\right)$ sebesar 0.718. Nilai tersebut mempunyai maksud bahwa pengaruh kecerdasan emosional, motivasi kerja dan kualitas kehidupan kerja terhadap kinerja pegawai di Badan Kepegawaian Daerah Kabupaten Labuhanbatu Selatan sebesar $71.80 \%$, sedangkan sisanya sebesar $28.20 \%$ 
dipengaruhi oleh faktor-faktor lain yang tidak diteliti. Dengan kata lain variabel kinerja pegawai di Badan Kepegawaian Daerah Kabupaten Labuhanbatu Selatan dapat diterangkan oleh variabel kecerdasan emosional, motivasi kerja dan kualitas kehidupan kerja sebesar $71.80 \%$, sedangkan sisanya sebesar $28.20 \%$ disebabkan oleh variabel-variabel lain yang tidak diteliti seperti gaji, fasilitas kerja, kepemimpinan dan lain sebagainya.

\section{Pembahasan}

\subsection{Pengaruh Kecerdasan Emosional Terhadap Kinerja Pegawai di Badan Kepegawaian Daerah Kabupaten Labuhanbatu Selatan.}

Berdasarkan pada hasil penelitian dapat dijelaskan bahwa kecerdasan emosional berpengaruh positif dan signifikan terhadap kinerja pegawai di Badan Kepegawaian Daerah Kabupaten Labuhanbatu Selatan, hal ini didukung dengan hasil uji hipotesis yang menunjukkan bahwa nilai $t_{\text {hitung }}>t_{\text {tabel }}$ (3.969 > 2.036) dan nilai signifikasi lebih kecil dari nilai $\alpha: 0.05$ yaitu $0.000<0.05$. Hasil penelitian ini sejalan dengan hasil penelitian terdahulu dari Danquah, M. E. (2014); Gani et.al (2018); Supriadi dan Sefnedi (2017), keduanya menyatakan bahwa kecerdasan emosional berpengaruh positif dan signifikan terhadap kinerja. Akan tetapi hasil penelitian bertentangan dengan hasil penelitian terdahulu dari Ari Soeti Yani dan Ayu Istiqomah (2016); dan Thea et.al (2019), yang membuat kesimpulan bahwa kecerdasan emosional berpengaruh negatif dan tidak signifikan terhadap kinerja. Dari hasil penelitian ini dapat dijelaskan bahwa kecerdasan emosional pegawai di Badan Kepegawaian Daerah Kabupaten Labuhanbatu Selatan secara keseluruhan pada saat ini dalam kategori baik dan dapat meningkatkan kinerja pegawai.

\subsection{Pengaruh Motivasi Kerja Terhadap Kinerja Pegawai di Badan Kepegawaian Daerah Kabupaten Labuhanbatu Selatan.}

Berdasarkan pada hasil penelitian dapat dijelaskan bahwa motivasi kerja berpengaruh positif dan signifikan terhadap kinerja pegawai di Badan Kepegawaian Daerah Kabupaten Labuhanbatu Selatan, hal ini didukung dengan hasil uji hipotesis yang menunjukkan bahwa nilai $t_{\text {hitung }}>t_{\text {tabel }}(2.990>2.036)$ dan nilai signifikasi lebih kecil dari nilai $\alpha: 0.05$ yaitu $0.006<0.05$. Hasil penelitian ini sejalan dengan hasil penelitian terdahulu dari Agus Marimin (2011); Ali, A.Y.S., Dahie, A.M., dan Ali, A.A. (2016); Murgianto, Sulasmi, S., dan Suhermin. (2016); Nisyak, Ila Rohmatun., dan Trijonowati. (2016); Noviansyah dan Zunaidah (2011); Saeed, S., dan Syah, F.M (2016); Yazid, Musnadi dan Chan, (2013) kesemuanya menyatakan bahwa motivasi kerja berpengaruh positif dan signifikan terhadap kinerja. Dari hasil penelitian ini dapat dijelaskan bahwa motivasi kerja yang tercipta di Badan Kepegawaian Daerah Kabupaten Labuhanbatu Selatan secara keseluruhan pada saat ini dalam kategori baik dan dapat meningkatkan kinerja pegawai.

\subsection{Pengaruh Kualitas Kehidupan Kerja Terhadap Kinerja Pegawai di Badan Kepegawaian Daerah Kabupaten Labuhanbatu Selatan.}

Berdasarkan pada hasil penelitian dapat dijelaskan bahwa kualitas kehidupan kerja berpengaruh positif dan signifikan terhadap kinerja pegawai di Badan Kepegawaian Daerah Kabupaten Labuhanbatu Selatan, hal ini didukung dengan hasil uji hipotesis yang menunjukkan bahwa nilai $t_{\text {hitung }}>t_{\text {tabel }}$ (3.686 > 2.036) dan nilai signifikasi lebih kecil dari nilai $\alpha: 0.05$ yaitu $0.001<0.05$. Hasil penelitian ini sejalan dengan hasil penelitian terdahulu dari Majundar (2012) dan Taglavi (2014), kesemuanya menyatakan bahwa kualitas kehidupan kerja berpengaruh positif dan signifikan terhadap kinerja. Dari hasil penelitian ini dapat dijelaskan bahwa kualitas kehidupan kerja pegawai di Badan Kepegawaian Daerah Kabupaten Labuhanbatu Selatan secara keseluruhan pada saat ini dalam kategori baik dan dapat meningkatkan kinerja pegawai

\section{Kesimpulan}

1) Kecerdasan emosional berpengaruh positif dan signifikan terhadap kinerja pegawai Badan Kepegawaian Daerah Kabupaten Labuhanbatu Selatan.

2) Motivasi kerja berpengaruh positif dan signifikan terhadap kinerja pegawai Badan Kepegawaian Daerah Kabupaten Labuhanbatu Selatan.

3) Kualitas kehidupan kerja berpengaruh positif dan signifikan terhadap kinerja pegawai Badan Kepegawaian Daerah Kabupaten Labuhanbatu Selatan. 
4) Kecerdasan emosional, motivasi kerja dan kualitas kehidupan kerja berpengaruh positif dan signifikan terhadap kinerja pegawai Badan Kepegawaian Daerah Kabupaten Labuhanbatu Selatan.

\section{DAFTAR PUSTAKA}

Adlina Setiani (2014), Kualiatas Kehidupan Kerja Terhadap Kinerja Dengan Komitmen Organisasi Intervening Variabel, e-Journal adbisnis Fisip Unmul.ac.id

Agus Marimin (2011), Pengaruh gaya kepemimpinan, motivasi kerja, dan budaya organisasi terhadap kinerja karyawan pada Bank Muamalat Indonesia Cabang Surakarta, Jurnal Manajemen dan Bisnis Sriwijaya Vol.3 No.16

Ali, A.Y.S., Dahie, A.M., dan Ali, A.A. (2016). Teacher Motivation and Leadership, the Mediating Effect of Job Performance: Survey from Secondary Schools in Mogadishu. International Journal of Education and Social Science Vol. 3 No. 1. January 2016

Alia, Cut Fauza, Mukhlis Yunus dan Mahdani (2015), "Pengaruh Budaya Perusahaan, Rotasi Dan Promosi Jabatan Terhadap Motivasi Serta Implikasinya Pada Kinerja Karyawan PT. Bank Mandiri (Persero) Tbk. Area Banda Aceh." Jurnal Manajemen Pascasarjana Universitas Syiah Kuala. ISSN: 2302- 0199. Vol. 4, No. 1, Hal. 1-10.

Anak Agung Ngurah Bagus Dhermawan, I Gde Adnyana Sudibya, I Wayan Mudiartha Utama (2012), Pengaruh Motivasi, Lingkungan Kerja, Kompetensi, Dan Kompensasi Terhadap Kepuasan Kerja Dan Kinerja Pegawai Di Lingkungan Kantor Dinas Pekerjaan Umum Provinsi Bali, Jurnal Manajemen, Strategi Bisnis, dan Kewirausahaan Vol. 6, No. 2 Agustus 2012.

Arozi, Yaomul Fahru (2011). Pengaruh Kemampuan Kerja dan Motivasi Kerja terhadap Kinerja Karyawan PT. Kereta Api (Persero) DAOP IV Semarang. Skripsi. Semarang : Universitas Diponegoro

Anoraga, Panji (2014). Psikologi Kerja, PT Rineka Cipta, Jakarta

Ari Soeti Yani dan Ayu Istiqomah (2016), Pengaruh Kecerdasan Intelektual Dan Kecerdasan Emosional Terhadap Kinerja Karyawan Dengan Profesionalisme Sebagai Variabel Intervening (Studi
Empiris Terhadap PT. JNE Service Center Utara). Media Studi Ekonomi, Volume 19 No. 2 ,Juni Desember 2016

Cascio, Wayne F.,( (2012) Managing Human Resources: Productivity, Quality of Work Life, Profits, edition, New York, McGraw Hill

Colquitt, J. A., LePine, J. A., and Wesson., (2009) Organizational Behavior: Improving Performance and Commitment in the Workplace, New York, McGraw Hill, pp. 37

Cross, T.M dan Lynch. R.R. (2002). Peniliaian dan Evaluasi Kinerja: Konsep dan Praktik. Jakarta. Penerbit Ghalia Indonesia

Danquah, M. E. (2014). Analysis Of The Impact Of Emotonal Intelligence On Organisational Performance: A Banking Perspective. British Journal of Marketing Studies,Vol.2, No.3, pp.34-50, July 2014

Dessler, Gary. (2012). Manajemen Sumber Daya Manusia (Jilid I). Jakarta : Indeks.

Farlen, Frans (2011). Pengaruh Motivasi Kerja dan Kemampuan Kerja terhadap Kinerja Karyawan (Studi pada karyawan PT. United Tractors, Tbk Samarinda). Skripsi. Yogyakarta : Universitas Pembangunan Nasional "Veteran

Fitriadi, B. Y. (2012). Analisis pengaruh kualitas kehidupan kerja terhadap motivasi kerja dan kinerja karyawan PT. Bank Muamalat Indonesia Jember. Skripsi. Universitas Jember: Fakultas Ekonomi

Gibson, James L., Ivancevich, John M., Donnely, James H., and Konopaske (2009) Organizations: Behavior, Structure, Processes, New York, McGraw Hill.

Hasibuan, Malayu S. P. (2011). Manajemen Sumber Daya Manusia. Edisi Revisi Jakarta: PT. Bumi Aksara.

Husaini, Musnadi,S., \& Amri, (2017). Pengaruh Kepribadian, Komitmen Kerja Dan Kematangan Emosional Terhadap Motivasi Kerja Dan Dampaknya Terhadap Kinerja Perawat Di Badan Layanan Umum Daerah (BLUD) Rumah Sakit Jiwa Aceh. Jurnal Magister Manajemen Fakultas Ekonomi dan Bisnis Unsyiah. 1(1)

Koesmono, H. Teman, (2005). Pengaruh Budaya Organisasi terhadap Motivasi dan Kepuasan Kerja serta Kinerja Karyawan pada Sub Sektor Industri Pengolahan Kayu Ekspor di Jawa Timur. Disertasi. Universitas Airlangga. Surabaya 
Kusuma, A. A. (2013). Pengaruh motivasi dan lingkungan kerja terhadap kinerja karyawan Hotel Muria Semarang. Skripsi. Universitas Negeri Semarang: Fakultas Ekonomi

Majundar Nandi Malini, Daun Debormita, Dutta Avijan. (2012). Impact of QWL on Job Performance: A case Study on Indian Telecom Sector. International Journal of Arts \& Sciences. ISSN 19446934:5(6):655-685

Mangkunegara, Anwar, Prabu. (2015). Evaluasi Kinerja SDM, Cetakan 4, Bandung : Refika Aditama

Mangkuprawira, Sjafri. (2014). Manajemen Sumber Daya Manusia Strategik. Cetakan ketiga, Penerbit Ghalia Indonesia

Murphy, S. E., and Pirozzolo, F. J., (2002) Multi Journal ple Intelligences and Leadership, New Jersey, Lawrence Erlbaum

Muslih, Basthoumi. (2012). Analisis Pengaruh Motivasi Terhadap Kepuasan Kerja dan Kinerja Pegawai di PT Sang Hyang Seri (Persero) Regional III Malang. Jurnal Aplikasi Manajemen. Vol.10. No.4

Murgianto, Sulasmi, S., dan Suhermin. (2016). Effects of Commitment, Competence, Work Satisfaction on Motivation and Performance of Employees at Integrated Service Office of east Java. International Journal of Advanced Research (2016), Volume 3, Issue -378-396

Nisyak, Ila Rohmatun., dan Trijonowati. (2016), Pengaruh Gaya Kepemimpinan, Motivasi dan Disiplin Kerja Terhadap Kinerja Karyawan. Jurnal Ilmu dan Riset Manajemen : Volume 5, Nomor 4, April 2016. STIESIA

Noviansyah dan Zunaidah (2011). Pengaruh sikap kerja dan motivasi kerja terhadap kinerja pegawai PT. Perkebunan Minanga Ogan Baturaja. Jurnal Manajemen dan Bisnis Sriwijaya Vol.9 No.18

Rahmawati, Enny, Y. Warella dan Zaenal Hidayat, (2006), Pengaruh Motivasi Kerja, Kemampuan Kerja dan Gaya Kepemimpinan terhadap Kinerja Karyawan pada Badan Kesatuan Bangsa dan Perlindungan Masayarakat Provinsi Jawa Tengah. Dialogue, Jurnal Ilmu Administrasi dan Kebijakan Publik, Vol. 3 No. 1, Januari hal. 89-97

Ridwan. (2012). Skala Pengukuran VariabelVariabel Bandung : Alfabeta
Rivai, Veithzal dan Sagala, Ella Jauvani. (2009). Manajemen Sumber Daya Manusia Untuk Perusahaan : Dari Teori ke Praktek. Jakarta : PT. Rajagrafindo Persada

Robbins, Stephen P., dan Judge, Timothy A., (2011) Perilaku Organisasi, Terjemahan Edisi Dua Belas, Jakarta, Salemba Empat. (2009) Organizational Behavior, $13^{\text {th }}$ edition, New Jersey, Pearson Education, Upper Saddle River.

Robbins, Stephen P., and Coulter, Mary., (2012) Management, New Jersey, Pearson Prentice Hall, pp. 489

Sedarmayanti. (2014). Good Governance (Kepemerintahan Yang Baik), Bandung : Mandar Maju

Sekaran, U., dan Bougie (2010), Research Methods for Busines. A Skill Building Approach. Fifth Edition. A John Wiley and Sons, Ltd, Publication.

Siagian, Sondang. (2013). Manajemen Sumber Daya Manusia (cetakan 15). Jakarta: Bumi Aksara

Sink, R dan Tuttle, J.K. (2009). Evaluasi Kinerja. Jakarta: Indeks Kelompok Gramedia.

Smithson, Janet., Suzan Lewis (2012). Is job insecurity changing the psychological contrac, Personnel Review ,29(6):1-15

Sri Handoko Budi Nugroho, Achmad Choerudin, Winarna (2012), Pengaruh Budaya Kerja dan Lingkungan Kerja terhadap Kinerja melalui Motivasi dan Komitmen Organisasi (Studi di Komisi Pemilihan Umum Kabupaten Karanganyar), Downloads/165-321-1SM.pdf.

Stone, Raymond., (2005) Human Resource Management, Fifth Edition, Australia, John Wiley \& Sons

Supriadi dan Sefnedi (2017), The effect of emotional intelligence and organizational cynicism on job performance : The role of motivation as mediator, IOSR Journal of Business and Management (IOSR-JBM), e-ISSN: 2278-487X, p-ISSN: 2319-7668. Volume 19, Issue 3. Ver. II (Mar. 2017), PP 101-107

Suryana Sumantri (2011). Perilaku Organisasi. Bandung: Universitas Padjadjaran

Sutrisno, Edy (2014). Manajemen Sumber Daya Manusia, Kencana Prenada Media Group Jakarta 
Taghavi, Safura., Ebrahimzadeh, Fariman., Bhramzadh, Hossein Ali., dan Masoumeh, Hosseini., (2014) "A Study of the Relationship Between Quality of Worklife and Performance Effectiveness of High School Teachers in Shirvan", International Journal of Academic Research in Business and Social Sciences, Vol. 4, No. 1, ISSN : 2222-6990

Thea Azalia Lansart, Bernhard Tewal, Lucky O.H Dotulong (2019), Pengaruh Kecerdasan Emosional, Dukungan Organisasi Dan Keadilan Organisasional Terhadap Kinerja Pegawai Di Biro Organisasi Sekretariat Daerah Pemerintah Provinsi Sulawesi Utara, Jurnal EMBA, Vol.7 No.4 Oktober 2019, Hal. 5593-5602

Wibowo, (2016), Manajemen Kinerja, Edisi Kelima, PT.Rajagrafindo Persada Jakarta14240.

Widodo Eko Suparno. (2015). Manajemen Pengembangan Sumber Daya Manusia.Yogyakarta: Pustaka Pelajar

Yazid, Musnadi dan Chan, (2013). Pengaruh Gaya Kepemimpinan, Budaya Organisasi dan Motivasi Kerja Terhadap Prestasi Pegawai Administrasi serta Dampaknya pada Kinerja Politeknik Negeri Lhoseumawe, Aceh. Jurnal Manajemen Pascasarjana Universitas Syiah Kuala. ISSN 2302-0199. pp. 78- 87

Yunaini, Agus Supriono, Alfi Hidayati, Ansyari (2020), Pengaruh Kematangan Emosional, Kualitas Kehidupan Kerja dan Motivasi Terhadap Kinerja Pegawai Kantor Kementrian Agama Kabupaten Batubara, Jurnal Riset Manajemen \& Bisnis, Vol. 5 No. 2 Nopember 2020

Zin, R. M., (2014) "Perception of Professional Engineers Toward Quality of Work Life and Organizational Commitment a Case Study", Gadjah Mada InternationalJournal of Business, 6(3), 323-334 